\title{
БИОДИАГНОСТИКА ЭКОЛОГИЧЕСКОГО СОСТОЯНИЯ ПОЧВ РЕКРЕАЦИОННОЙ ЗОНЫ Г. ВОРОНЕЖА
}

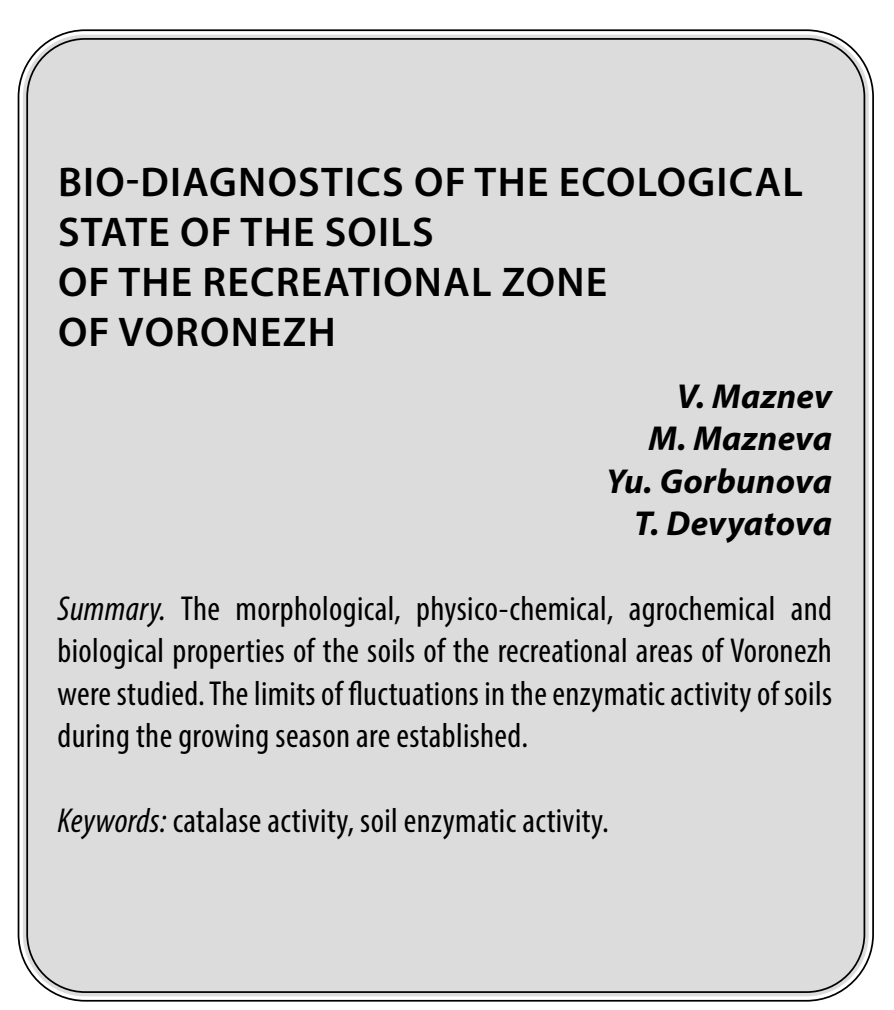

B настоящее время особое значение приобретает разработка целостной концепции оценки антропогенной динамики экосистем, не только по показателям биоразнообразия, принятым нормативам содержания полютантов в их компонентах, но и биологическим свойствам почв, которые являются наиболее динамичными и позволяющими проводить раннюю диагностику любых изменений в экосистемах. Весьма весомый вклад в суммарные показатели биологической активности почв вносят ферменты, выступающие в качестве редуцентов органических остатков, техногенных загрязнителей и участвующие в выполнении одной из важнейших функций почвы в экосистеме - превращении вещества и энергии как в естественных, так и нарушенных деятельностью человека экосистемах. Работа ферментов определяет доступность элементов питания, гумусное состояние, азотный, фосфорный, серный режим почв и ее способность к детоксикации различных полютантов $[2,3,5]$.

На возможность использования показателей ферментативной активности почв в качестве индикаторов их антропогенной деградации указывали многие авторы $[1,6]$. Наиболее чувствительным среди почвенных
Мазнев Владислав Юрьевич

Аспирант, Воронежский Государственный университет

d.wade5@mail.ru

Мазнева Марина Алексеевна

Воронежский Государственный университет marina.novokhatskikh@mail.ru

Горбунова Юлия Сергеевна

К.б.н., дочент, Воронежский Государственный университет

gorbunova.vsu@mail.ru

Девятова Татьяна Анатольевна

Д.б.н., профрессор, Воронежский Государственный университет devyatova@bio.vsu.ru

Аннотация. Исследованы морфологические, физико-химические, агрохимические и биологические свойства почв рекреационных территорий г. Воронежа. Установлены пределы колебаний ферментативной активности почв в течение вегетационного периода.

Ключевые слова: каталазная активность, ферментативная активность почв.

ферментов к действию различных техногенных факторов является каталаза. Многие авторы указывают на зависимость каталазной активности почв от ее физических свойств и экологического состояния растений, произрастающих на ней [2].

Каталаза - широко распространенный фермент, присуща всем живым организмам, участвует в почве в окислительном распаде продуктов разложения органических остатков.

\section{Це^ь \\ исслеАования}

Определить интенсивность окислительно-восстановительных процессов в почвах экосистем, подверженных интенсивной рекреационной нагрузке.

Задачи:

- провести определение физико-химических и агрохимических показателей почв;

- определить каталазную активность почвы представительных участков с высоким уровнем рекреационной нагрузки; 
Таблица 1. Физико-химические свойства темно-серой лесной почвы

\begin{tabular}{|c|c|c|c|c|c|c|c|c|c|}
\hline \multirow{2}{*}{$\begin{array}{l}\text { Категории } \\
\text { земель }\end{array}$} & \multirow[t]{2}{*}{ Почва } & \multirow[t]{2}{*}{ Глубина, см } & рН сол. & $\mathrm{Hr}$ & $\mathrm{Ca}^{2+}$ & $\mathbf{M g}^{2+}$ & $\begin{array}{l}\mathrm{Ca}^{2+} \\
\mathbf{M g}^{2+}\end{array}$ & Емкость погл. & \multirow[t]{2}{*}{$V, \%$} \\
\hline & & & \multicolumn{6}{|c|}{ Мг-эКв/100 г почвы } & \\
\hline \multirow{6}{*}{$\begin{array}{l}\text { Земли } \\
\text { рекреационной } \\
\text { зоны }\end{array}$} & \multirow{2}{*}{ серая лесная } & $0-10$ & 5,8 & 2,3 & 10,5 & 1,5 & 12,0 & 14,3 & 84 \\
\hline & & $10-20$ & 5,8 & 2,5 & 7,5 & 1,5 & 9,0 & 11,5 & 78 \\
\hline & \multirow{2}{*}{$\begin{array}{l}\text { чернозем } \\
\text { выщелоченный }\end{array}$} & $0-10$ & 6,8 & 1,3 & 24,4 & 1,8 & 26,2 & 27,5 & 90 \\
\hline & & $10-20$ & 6,5 & 1,5 & 24,3 & 1,9 & 25,2 & 26,5 & 95 \\
\hline & \multirow{2}{*}{ урбанозем } & $0-10$ & 7,3 & 0 & 18,4 & 1,5 & 19,9 & 21,4 & 100 \\
\hline & & $10-20$ & 7,4 & 0 & 18,8 & 1,8 & 20,6 & 22,4 & 100 \\
\hline
\end{tabular}

Таблица 2. Агрохимические свойства почв

\begin{tabular}{|c|c|c|c|c|c|c|c|c|}
\hline \multirow{2}{*}{ Земли } & \multirow{2}{*}{ Почва } & \multirow{2}{*}{$\begin{array}{l}\text { Глубина, } \\
\text { см }\end{array}$} & Гумус,\% & $\mathbf{N}_{\text {оби. }}$ & N-NH ${ }_{4}$ & $\mathrm{~N}-\mathrm{NO}_{3}$ & $\mathbf{P}_{2} \mathbf{O}_{5}$ & $\mathrm{~K}_{2} \mathrm{O}$ \\
\hline & & & \multicolumn{3}{|c|}{ Мг/Кг почвы } & \multicolumn{3}{|c|}{ мг/100 г почвы } \\
\hline \multirow{6}{*}{$\begin{array}{l}\text { Земли } \\
\text { рекреационной } \\
\text { зоны }\end{array}$} & \multirow{2}{*}{\begin{tabular}{|l} 
чернозем \\
выщелоченный
\end{tabular}} & $0-10$ & 5,3 & 2473 & 16,3 & 21,8 & 24,9 & 30,5 \\
\hline & & $10-20$ & 4,9 & 2208 & 15,4 & 21,7 & 25,1 & 19,3 \\
\hline & \multirow{2}{*}{ серая лесная } & $0-10$ & 5,0 & 2340 & 20,6 & 46,5 & 13,7 & 27,5 \\
\hline & & $10-20$ & 4,9 & 2340 & 19,4 & 41,3 & 16,8 & 15,5 \\
\hline & \multirow{2}{*}{ урбанозем } & $0-10$ & 4,2 & 2184 & 18,3 & 38,1 & 7,8 & 29,4 \\
\hline & & $10-20$ & 4,0 & 2006 & 16,4 & 37,3 & 4,6 & 12,6 \\
\hline
\end{tabular}

Таблица 3. Каталазная активность почв различных рекреационных территорий

\begin{tabular}{|c|c|c|c|c|c|c|}
\hline \multirow[t]{2}{*}{ № $\Pi / \Pi$} & \multirow[t]{2}{*}{ Объект } & \multirow[t]{2}{*}{ Почва } & \multirow[t]{2}{*}{ Глубина, см } & \multicolumn{3}{|c|}{$\begin{array}{l}\text { Каталазная активность, мм } \\
\text { O }_{2} \text { за } 1 \text { мин }\end{array}$} \\
\hline & & & & май & июль & сентябрь \\
\hline \multirow{2}{*}{1} & \multirow{2}{*}{ ЦПКиО «Динамо» } & серые лесные & $0-15$ & 2,4 & 2,9 & 2,1 \\
\hline & & чернозем выщелоченный & $0-15$ & 2,9 & 3,7 & 3,4 \\
\hline 2 & Дендрарий ВГлту & серые лесные & $0-15$ & 2,8 & 3,4 & 2,5 \\
\hline \multirow{2}{*}{3} & \multirow{2}{*}{$\begin{array}{l}\text { Левобережное } \\
\text { лесничество }\end{array}$} & серые лесные & $0-15$ & 3,3 & 3,6 & 3,0 \\
\hline & & урбанозем & $0-15$ & 1,9 & 2,2 & 2,0 \\
\hline
\end{tabular}

- провести сравнительный анализ результатов исследования фоновых почв и почв рекреационных территорий.

\section{Объекты и метолы исслеАования}

Исследования проводили на территории г. Воронежа. Воронеж - крупнейший промышленный центр Центрального черноземья, занимает площадь более 600 кM², население более миллиона человек. Расположен на Юго-восточной окраине Среднерусской возвышенности в бассейне среднего Дона. Город вытянут с севера на юг более, чем на 20 км, а с запада на восток - на 10 км. В меридианальном направлении территорию города пересекает долина реки Воронеж, расширяющаяся в черте города в пределах акватории созданного в 1972 году во- дохранилища. В зональном отношении Воронеж и Подворонежье - это типичная лесостепь с преобладающими на водоразделах выщелоченными черноземами, а в поймах р. Дон и р. Воронеж - аллювиальными почвами легкого гранулометрического состава.

За более чем 400 летнюю историю города, в результате строительных работ с перемещением грунта, переуплотнения, загрязнения промышленными, транспортными и бытовыми отходами сформировались урбаноземы. Их отличительными чертами являются: отсутствие генетических горизонтов, повышенная плотность, включения мусора, наличие загрязняющих веществ. В рекреационных зонах города сохранились ненарушенные почвы, обладающие определенной биологической продуктивностью. 
Морфологическое описание почвы рекреационной территории приводим на примере разреза, заложенного в дендрарии лесотехнического университета.

Координаты 51.716572, 39.220151

Угодье: лесопарк, клен, липа, дуб (150 лет).

Рельеф:

макро: Окско-Донская низменность;

мезо: ровная поверхность;

микро: приствольные повышения.

(0+10 см) лесная подстилка

AU (0-20 см) свежий серовато-бурый, зернисто комковатый, среднесуглинистый, плотный, пористый, корни растений.

AUe (20-34 см) увлажнен, бурый, с серым оттенком зернисто -комковатый, легкий суглинок, плотный, пористый, корни растений.

BEL (35-59 см) увлажнен, бурый, призмовидно-комковатая, среднесуглинистый, плотный, пористый, корни растений.

ВТ (60-84 см) увлажнен, желтовато-бурый, призмовидно-ореховатый, тяжело суглинистый, плотный, пористый.

C (85-130 см) увлажнен, желто-бурый, призмовидно-комковатый, супесчаный, плотный, карбонаты.

Почва: AU-AUe-BEL-BT-C.

Темно-серая типичная маломощная среднесуглинистая на аллювиальных супесчаных отложениях.

\section{Метолы исследования}

Физико-химические и агрохимические свойства почвы определяли общепринятыми методами, активность каталазы определяли газометрическим методом $[2,4]$.

\section{Обсужление результатов}

Реакция среды слабокислая, близкая к нейтральной, состояние почвенно-поглощающего комплекса почв является типичным для естественных типов, емкость катионного обмена составляет 14,3 мг-экв/100 г. почвы, степень насыщенности основаниями - 84\%.

Содержание гумуса достаточно высокое (5,3\%), что связано со значительным ежегодным растительным опадом. Содержание соединений азота, фосфора и калия колеблется в пределах естественных фоновых значений.

Каталазная активность почвы высокая, что свидетельствует о высокой скорости биохимических реакций окисления органических веществ в почве, что связано, вероятно с оптимальным содержанием субстрата и благоприятным термическим режимом.

Исследование сезонной динамики каталазной активности почвы показало, что наибольшая активность наблюдается в июле, достигая минимума к концу сентября, что объясняется, очевидно, резким ухудшением осенью воздушного режима почвы в связи с переувлажнением и снижением температуры.

\section{Зак^ючение}

Результаты исследований свидетельствуют об активных процессах разложения перекиси водорода, образующейся в процессе окисления неспецифических органических веществ в почвах рекреационной зоны г. Воронежа, что позволяет использовать данный показатель для биоиндикации почв городских ландшафтов.

\section{ЛИТЕРАТУРА}

1. Вальков, В.Ф. Почвоведение: учебник для академического бакалавриата / В.Ф. Вальков, К.Ш. Казеев, С.И. Колесников. - 4-е изд., перераб. и доп. Москва: Изд-во Юрайт, 2018. - 527 с.

2. Девятова Т.А. Биодиагностика почв: учебное пособие / Т.А. Девятова, Т.Н. Крамарева. — Воронеж: Изд-во полиграф. центр ВГУ, 2008. — С. 50-52.

3. Добровольский Г.В. География почв / Г.В. Добровольский, И.С. Урусевская. — М.: Изд-во: МГУ, 2004. - 89 с.

4. Строганова М.Н. Экологическое состояние почвенного покрова урбанизированных территорий / М.Н. Строганова, М.Г. Агаркова, В.М. Жевелева // Экологические исследования в Москве и Московской области. - М.: Наука, 1990. - С. 127-147.

5. Хазиев Ф.Х. Методы почвенной энзимологии / Ф.Х. Хазиев. М.: Наука, 1990. - 189с.

6. Blume H.P. Classification of soils in urban agglomerations / H.P. Blume — Catena. Vol. 16. 1989. P. 259-273.

\footnotetext{
○ Мазнев Владислав Юрьевич ( d.wade5@mail.ru ), Мазнева Марина Алексеевна ( marina.novokhatskikh@mail.ru ), Горбунова Юлия Сергеевна ( gorbunova.vsu@mail.ru ), Девятова Татьяна Анатольевна (devyatova@bio.vsu.ru). Журнал «Современная наука: актуальные проблемы теории и практики»
} 